\title{
Productivity of Indigofera zollingeriana under Different Canopy and Soil Acidity Level in Oil Palm Estate
}

\author{
Herdiawan I \\ ${ }^{1}$ Indonesian Research Institue of Animal Production \\ Jl. Veteran III Banjarwaru Ciawi PO Box 221 Bogor Indonesia \\ E-mail: herdiawanmaliq@gmail.com \\ (received 11-02-2016; revised 27-05-2016; accepted 09-06-2016)
}

\begin{abstract}
ABSTRAK
Herdiawan I. 2016. Produktivitas Indigofera zollingeriana pada berbagai taraf naungan dan kemasaman tanah di lahan perkebunan kelapa sawit. JITV 21(2): 135-143. DOI: http://dx.doi.org/10.14334/jitv.v21i2.1361

Lahan perkebunan kelapa sawit di Indonesia sangat luas dan umumnya berada pada lahan sub-optimal yang berpeluang besar bagi pengembangan peternakan dalam penyediaan hijauan pakan. Penelitian bertujuan untuk mengetahui produktivitas Indigofera zollingeriana pada berbagai taraf naungan. Penelitian menggunakan rancangan RAK faktorial dengan 2 taraf perlakuan yaitu 3 taraf naungan umur kelapa sawit 2, 5 dan 7 tahun dan 2 taraf kemasaman tanah yaitu netral dan masam, masing-masing perlakuan diulang sebanyak 4 kali. Peubah yang diamati adalah produksi, dan kandungan nutrisi tanaman. Hasil penelitian menunjukkan tidak terdapat interaksi antara taraf naungan kelapa sawit dengan kemasaman tanah terhadap produksi segar daun, batang/ranting, biomasa, dan nisbah daun/ranting I. zollingeriana. Produksi segar daun, batang, biomasa, dan nisbah daun/ranting I. zollingeriana sangat nyata $(\mathrm{P}<0,01)$ menurun sejalan dengan taraf naungan. Kemasaman tanah nyata $(\mathrm{P}<0,05)$ menurunkan produksi segar daun, batang, biomasa, dan nisbah daun/ranting. Taraf perlakuan naungan nyata $(\mathrm{P}<0,05)$ meningkatkan kandungan protein kasar, serat kasar, dan energi, sebaliknya nilai kecernaan in vitro bahan kering dan bahan organik menurun. Kemasaman tanah nyata $(\mathrm{P}<0,05)$ menurunkan kandungan kasium, kecernaan in vitro bahan kering dan bahan organik I. zollingeriana.
\end{abstract}

Kata Kunci: Indigofera zollingeriana, Perkebunan Kelapa Sawit, Naungan, Tanah Masam

\begin{abstract}
Herdiawan I. 2016. Productivity of Indigofera zollingeriana under different canopy and soil acidity level in oil palm estate. JITV 21(2): 135-143. DOI: http://dx.doi.org/10.14334/jitv.v21i2.1361

Oil palm estate area in Indonesia is generally located in a sub-optimal land that has great opportunity for the development of forage supply. This study aims were to determine productivity of Indigofera zollingeriana under various canopy level. This research used factorial randomized block design with 3 canopy levels (under 2, 5, and 7 year oil palm canopy) and 2 levels of soil acidity (neutral and acid soil) treatments, where each treatment was repeated 4 times. Parameters observed were production and nutrient content of Indigofera zollingeriana. Research results showed that there was no interaction between the canopy levels and soil acidity on the production of fresh leaves, stems/branches, biomass, and leaves/stem ratio of I. zollingeriana. Production of fresh leaves, stems, biomass, and leaves/branches ratio of I. zollingeriana significantly $(\mathrm{P}<0.01)$ decreased along with increase of canopy level. Soil acidity significantly $(\mathrm{P}<0.05)$ decreased production of fresh leaves, stems, biomass, and leaves/branches ratio. Level of canopy treatment significantly $(\mathrm{P}<0.05)$ increased content of crude protein, crude fiber and energy, otherwise value of in vitro dry matter digestibility (IVDMD) and organic matter digestibility (IVOMD) were decrease. Soil acidity significantly $(\mathrm{P}<0.05)$ decreased calcium content, in vitro dry matter digestibility (IVDMD) and organic matter digestibility (IVOMD) of I. zollingeriana.
\end{abstract}

Kata Kunci: Indigofera zollingeriana, Oil Palm Estate, Canopy, Acid Soil

\section{INTRODUCTION}

Limited forage land in Indonesia is caused by several factors such as limited land availability, competition with other use, and high land convertion number. Mulyani et al. (2011) said that most of the remaining land for forthcoming agricultural development was sub-optimal or marjinal land, such as rainfed land; acidic dryland and wetland with various biosfic issues. Atman (2006) reported that most of total area available in Indonesia $(190,946,500$ ha) for agriculture area were clasified as Ultisol or acidic dryland. Ultisol soil was drysoil with high abiotic stresses, such as soil $\mathrm{pH}<4$, organic content, low cation exchange capacity, and high $\mathrm{Mn}^{2+}$ and reactive aluminium $\left(\mathrm{Al}^{3+}\right)$ element which was able to poison plant root and preventing root nodule formation in legume (Hairiah et al. 2006). Then Subagyo et al. 
(2004) said that Ultisol land was more widely used for estate and protected forest area due to its high abiotic stresses. Nowadays, those lands were mostly used for oil palm estate around 5.3 million ha (CSA 2012). Therefore, oil palm estate is one of forage land resources.

Cultivation of forage in oil palm estate areal faces 2 main problems, that are low sunlight intensity and hight soil acidity stresses. Light intensity under forest vegetation largerly determines process of photosystesis, botanical composition, growth, and quality of forage nutrition available for ruminant (Blair et al. 1983). As Das et al. (2008) said that forage cultivation under oil palm estate areal was restricted by low soil $\mathrm{pH}$ and sunlight intensity along with oil palm growth decreasing forage production. Physiologically, canopy will decrease sunlight intensity required for assimilation process of plants below. Crowder \& Chheda (1982)said that decrease of incoming sunlight intensity significantly increased assimilation rate and $\mathrm{CO}_{2}$ income decreasing quality and quantity of canopyunderneath plants. Wilson \& Ludlow (1991) described that shading rate of estate plants canopy might reach $80 \%$ depending on variety of plant, plant spacing and age.

Wong \& Chin (1998) said that underneath-forage production decreased along with oil palm aged. Along with oil palm aged, sunlight penetrating oil palm leaves was getting low affecting production of dry material production of the underneath plants. Chin (1998) said that dry material production of forage under nursling oil palm plant might reach $1600-2600 \mathrm{~kg} / \mathrm{ha}$ and decreased to $600 \mathrm{~kg} / \mathrm{ha}$ along with oil palm aged. Low transmission affected microclimate under canopy and then decreasing soil temperature. This condition might prevent growth and dry material accumulation of plants growing under oil palm trees (Abdullah 2011). Horne (1994) described that there were 2 ways to improve and increase quality and production of forage under oil palm and rubber estates. One of them was ntroduction of shade-tolerant forage to support its sustainable production. Therefore, technologies of cultivation in certain oil palm age and shade-tolerant forage in such specific condition were required, so that productivity of forage positively contributed to the both sides.
Based on research results conducted in a greenhouse, I. zollingeriana had high tolerant against acidic soil stress than C.calothyrsus and G. sepium (Herdiawan \& Sutedi 2013). Subject of this study was to determine productivity of $I$. zollingeriana in acid soil condition and under oil palm canopy level to support oil palm-cattle integration.

\section{MATERIALS AND METHODS}

This study was conducted in oil palm estate in Deli Serdang district, North Sumatra by planting $I$. zollingeriana as an intercropping plant. Preparation step was conducted by sowing seed in seeding tray containing of $1: 1$ soil and compose until 4 weeks, and than moved to small polybag until 8 weeks old. Eight weeks old plants were moved to field by $2 \times 2 \mathrm{~m}$ row spacing and each plot size was $8 \times 30 \mathrm{~m}$. Planting was conducted between 2, 5, and 7 years old trees in acid and neutral soil condition by administratin super dolomite (5 ton/ha). This study used factorial Randomized Block Design (Gomez and Gomes, 1984) with 3 canopy levels and 2 soil acidity levels with 4 repetitions. Based on Solarimeter, average light intencities in 2 (control), 5 , and 7 years oil palm estate were $2632.90 \mathrm{cal} / \mathrm{m}^{2}, 1751.30 \mathrm{cal} / \mathrm{m}^{2}$ and $698.70 \mathrm{cal} / \mathrm{m}^{2}$, respectively. Soil acidity was assessed using $\mathrm{pH}$ tester and lacmus paper to soil administered by super dolomite ( $\mathrm{pH}$ 4.72). First pruning was conducted in 60 DAP (days after planting) and then harvested 1 meter above the ground in every 90 days. Parameters observed were production of biomass, leaves, brances, ration leaves/brances and nutrients content $(\mathrm{CP}, \mathrm{CF}$, Energy, $\mathrm{Ca}, \mathrm{P}$, in vitro digestibility of dry and organic materials)

\section{RESULTS AND DISCUSSION}

\section{Production of I. zollingeriana}

Based on analysis of variance, there was no interaction between canopy level and soil acidity to fresh biomass production of I. zollingeriana (Table 1).

Table 1. Fresh biomass production of I. zollingeriana in various canopy levels and soil acidity (g/plant) of oil palm estate

\begin{tabular}{lcccc}
\hline \hline \multirow{2}{*}{ Soil acidity } & \multicolumn{3}{c}{ Canopy level (age of oil palm) } & \multirow{2}{*}{ Average } \\
\cline { 2 - 4 } & 2 years & 5 years & 7 years & $2692.23^{\mathrm{a}}$ \\
\hline Neutral & 6701.59 & 1020.00 & 355.11 & $2640.52^{\mathrm{a}}$ \\
\hline Acid & 6645.24 & 92318 & 353.13 & $354.12^{\mathrm{c}}$ \\
\hline Average & $6673.42^{\mathrm{a}}$ & $971.59^{\mathrm{b}}$ & \\
\hline
\end{tabular}

The different letters in column and row shows significant difference $(\mathrm{P}<0.01)$ 
Table 2. Average production of fresh leaves of I. zollingeriana in various canopy levels and soil acidity (g/plant) of oil palm estate

\begin{tabular}{lllll}
\hline \hline \multirow{2}{*}{ Soil acidity } & \multicolumn{3}{c}{ Canopy level (age of oil palm) } & \multirow{2}{*}{ Average } \\
\cline { 2 - 4 } & 2 years & 5 years & 7 years & $1066.18^{\mathrm{a}}$ \\
\hline Neutral & 2800.30 & 301.17 & 97.08 & $1037.56^{\mathrm{b}}$ \\
\hline Acid & 2772.16 & 271.06 & 69.46 & $83.27^{\mathrm{c}}$ \\
\hline Average & $2785.23^{\mathrm{a}}$ & $286.12^{\mathrm{b}}$ & & \\
\hline
\end{tabular}

The different letters in column and row shows significant difference $(\mathrm{P}<0.01)$

Production of fresh biomass under 2 year oil palm canopy was significantly higher by $6701.59 \mathrm{~g} / \mathrm{plant}$. The lowest production of fresh biomass was under 7 years oil palm canopy by $353.13 \mathrm{~g} /$ plant. Meanwhile, administration of super dolomite was not significantly different. Total production of plants and roots of all plants was influenced by canopy, where production of plants under canopy was very low followed by production of uper-part biomass (Congdon \& Addison 2003). It was reported that average production of tropical forage biomass without canopy (control) was $40.11 \mathrm{~kg} /$ pot and decreased in $63 \%$ canopy level into $18.99 \mathrm{~kg} /$ pot. It sharply decreased from $76 \%$ and $84 \%$ into 7.08 and $6.27 \mathrm{~kg} / \mathrm{pot}$, respectively.

Farizaldi (2011) reported that production of forage dry material either grass and legume under 8 years oil palm trees was lower than in 5 and 3 years. This low production was caused by low light intencity due to bigger canopy shape along with oil palm aged. Batubara et al. (1999) said that older oil palm tree required more light, water and nutrient, so that its availability for underneath-plants was decrease. Average production of grass under 5-10 years oil palm trees was 10.479 ton/ha/year and increased into 14.827 ton/ha/year in 1020 years oil palm trees. Older oil palm trees had less canopy level, so that it received more light than the 510 years oil palm trees. Hanafi et al. (2005) reported his research results showing that production of fresh forage planting by monoculture under 55\% canopy level of oil palm was $(5890.73 \mathrm{~kg} / \mathrm{ha})$ better than under $75 \%$ canopy level (5347.26 ton/ha). Production of fresh forage per $\mathrm{m}^{2}$ of vegetation growing under 3 and 6 years oil palm trees was $386.54 \mathrm{~g} / \mathrm{m}^{2}$ and $189.29 \mathrm{~g} / \mathrm{m}^{2}$, respectively (Daru et al. 2014). Production of Indigofera zollingeriana biomass under 5 years oil palm trees was higher than native grasses under the same age of oil palm trees. Then there was a significant decrease of Indigofera zollingeriana production under 7 years oil palm trees.

Based on analysis of variance, there was no interaction between canopy level of oil palm and super dolomite adiminstration to production of fresh leaves of I. zollingeriana (Table 2). This was inaccordance with Jaramillo et al. (2010) who said that there was no significant interaction between canopy level and limestone application to production and leaves surface area per brance.

Production of fresh leaves under 2 years oil palm trees was the highest $(\mathrm{P}<0.01)$ by $2800.30 \mathrm{~g} / \mathrm{crop}$. The lowest production of fresh leaves was under 7 years oil palm trees by $69.46 \mathrm{~g} / \mathrm{crop}$. Canopy level and soil acidity significantly affected production of $I$. zollingeriana fresh leaves.

Di'az-Pe'rez (2013) reported that weight of leaves, stems and upper biomass were significantly different among the canopy level treatment. It was also reported that canopy changed plant morphologically with thiner and wider leaves and lighter weight. Atwell et al. (1999) also reported that plants growing under canopy would show horizontal adaptation response and smaller chloroplast. Canopy level by $40 \%$ decreased tomato leaves weight by $24 \%$ than the plants without canopy (Bertin \& Gary 1998). Then, Qifu et al. (2002) said that A1 content in high acid soil might disturb soy growth and ruined plant roots leading to low production of plant due to inefficiency of nutrient and water absorption by roots. Chen et al. (2005) said that A1 decreased $\mathrm{CO}_{2}$ intake useful in assimilation of tangerine (Citrus rehhni) affecting enzyme activities involved in Calvin cycle. Nutrients supply decreased by the assimilation process disruption decreasing production and quality of plants, especially in plants sensitive to A1 stress. Hilman et al. (2004) said that in acid dry land, phosphate $(\mathrm{P})$ availability was the main issue in increasing legume production.

Analysis of variance showed no interaction between canopy level of oil palm and soil acidity to production of fresh stems/branches of I. zollingeriana (Table 3).

The highest (3887.19 g/crop) production of fresh stems/braches was under 2 years oil palm trees and the lowest production by $270.85 \mathrm{~g} /$ plant was under 7 years oil palm trees. Meanwhile, administration of super dolomite was not significantly affected production of stems/branches of I. zollingeriana. Stems diameter shaded was thiner due to elongated growth than unshaded plants which affecting stems biomass. Larcher (1995) also said that stems diameter related to dry weight of upper plant, leaves area, and plant 
Table 3. Production of fresh stems/branches of $I$. zollingeriana in various canopy levels and soil acidity (g/plant) of oil palm estate

\begin{tabular}{lcccc}
\hline \hline \multirow{2}{*}{ Soil acidity } & \multicolumn{3}{c}{ Canopy level (age of oil palm) } & \multirow{2}{*}{ Average } \\
\cline { 2 - 4 } & 2 years & 5 years & 7 years & $1626.05^{\mathrm{a}}$ \\
\hline Neutral & 3901.29 & 718.83 & 258.03 & $1602.96^{\mathrm{a}}$ \\
\hline Acid & 3873.08 & 652.12 & 283.67 & \\
\hline Average & $3887.19^{\mathrm{a}}$ & $685.48^{\mathrm{b}}$ & $270.85^{\mathrm{c}}$ & \\
\hline
\end{tabular}

The different letters in column and row shows significant difference $(\mathrm{P}<0.01)$

Table 4. Ratio of leaves/branches of $I$. zollingeriana in various canopy levels and soil acidity (\%) of oil palm estate

\begin{tabular}{lcccc}
\hline \hline \multirow{2}{*}{ Soil acidity } & \multicolumn{3}{c}{ Canopy level (age of oil palm) } & \multirow{2}{*}{ Average } \\
\cline { 2 - 4 } & 2 years & 5 years & 7 years & $0.51^{\mathrm{a}}$ \\
\hline Neutral & 0.72 & 0.42 & 0.38 & $0.53^{\mathrm{a}}$ \\
Acid & 0.72 & 0.42 & 0.46 & $0.31^{\mathrm{c}}$ \\
\hline Average & $0.72^{\mathrm{a}}$ & $0.42^{\mathrm{b}}$ & \\
\hline
\end{tabular}

The different letters in column and row shows significant difference $(\mathrm{P}<0.01)$

ability to carry water from soil to leaves. Wilson \& Ludlow (1991) said that morphological responses of plants under canopy such as stems extention and branching reduce might decrease dry material production due to fewer axillary buds and same leaves area. Research resulted by Kittas et al. (2012) showed that chili plant under canopy had long stems, wider and thiner leaves and low leaves weight.

Research results showed no interaction between canopy level of oil palm and soil acidity to ratio of leaves/branches of $I$. zollingeriana. Ratio of leaves/branches under 2 years was significantly $(\mathrm{P}<0.01)$ higher by 0.72 than under 5 and 7 years by 0.42 and 0.31 , respectively. Ratio of leaves/branches in neutral and acid soil did not different (Table 4).

Shehu et al. (2001) said that ratio of leaves/branches was highly crucial since it was a metabolic organ and affected quality of legume. More leaves number showed better quality of legume. Leaves consisted highest nutrients than stems/branches. Ratio of crown/roots increased in plants under canopy due to increase of proportion of crown by sacrificing rooting system to obtain sufficient sunlight for assimilation process (Atwell et al. 1999). Alocation of resources excessively from roots to bud might lead susceptibility of plants to water stress periodically and intensive pruning. Too high root system decrease led decrase of DM production and longer recovery periode, where regrowth after defoliation related to carbohydrate and mineral reserves in root (Wilson \& Ludlow 1991). Karim et al. (1991) said that increasing plant age resulted lower ratio of leaves and branches. This low ratio affected crude protein and energy content. The most protein and energy was in branches, higher leaves ratio than branches produced higher protein and energy content which was crucial in animal productivity.

\section{Nutrient content of $I$. zollingeriana}

Based on analysis of variance, there was no interaction between oil palm canopy and soil acidity to crude protein content of I. zollingeriana (Table 5). Crude protein content of plnats under 2 years oil palm canopy was significantly higher $(\mathrm{P}<0.05)$ by $26.99 \%$ than that under 5 and 7 years oil palm by $23.15 \%$ and $25.61 \%$, respectively. Crude protein content in neutral and acid soil was not different. Daru et al. (2014) reported that crude protein content of plant under 6 years oil palm canopy was higher than that whout canopy. Canopy influenced forage quality either directly or indirectly changing chemical composition. Then, Wilson \& Wild (1995) said that N concentration in leaves consistently was higher under canopy than the one without canopy. Generally, there was high increase of $\mathrm{N}$ concentration in leaves in canopy treatment by $63 \%$ compared to the one without canopy. After all, canopy increase up to 76 and $84 \%$ was slighty increased $\mathrm{N}$ in leaves, but not in previous level.

$\mathrm{N}$ concentration of plant materials under canopy generally increased (Humphreys 2005). Congdon \& Addison (2003) said that N concentration in leaves was greatly influenced by canopy, where its concentration increased in under canopy than control, but there was no significantly change in $\mathrm{P}$ concentration in leaves. Kephart \& Buxton (1993) said that concentration of 
Herdiawan. Productivity of Indigofera zollingeriana under different canopy and soil acidity level in oil palm estate

Table 5. Crude protein content of I. zollingeriana in various canopy levels and soil Acidity (\%) of oil palm estate

\begin{tabular}{lcccc}
\hline \hline \multirow{2}{*}{ Soil acidity } & \multicolumn{3}{c}{ Canopy level (age of oil palm) } & Average \\
\cline { 2 - 4 } & 2 years & 5 years & 7 years & $24.99^{\mathrm{a}}$ \\
\hline Neutral & 23.94 & 25.20 & 26.83 & $24.48^{\mathrm{a}}$ \\
\hline Acid & 22.35 & 26.01 & 27.14 & $26.99^{\mathrm{a}}$ \\
\hline Average & $23.15^{\mathrm{c}}$ & $25.61^{\mathrm{b}}$ & & \\
\hline
\end{tabular}

The different letters in column and row shows significant difference $(\mathrm{P}<0.01)$

Table 6. Crude fiber content of I. zollingeriana in various canopy levels and soil acidity (\%) of oil palm estate

\begin{tabular}{lcccc}
\hline \hline \multirow{2}{*}{ Soil acidity } & \multicolumn{3}{c}{ Canopy level (age of oil palm) } & \multirow{2}{*}{ Average } \\
\cline { 2 - 4 } & 2 years & 5 years & 7 years & $16.51^{\mathrm{a}}$ \\
\hline Neutral & 14.76 & 17.10 & 17.68 & $16.24^{\mathrm{a}}$ \\
Acid & 12.37 & 18.22 & 18.12 & $17.90^{\mathrm{b}}$ \\
\hline Average & $13.57^{\mathrm{c}}$ & $17.66^{\mathrm{b}}$ & \\
\hline
\end{tabular}

The different letters in column and row shows significant difference $(\mathrm{P}<0.05)$

crude protein was much more responsive to canopy compared to other quality components. It was also said that $63 \%$ canopy might increase crude protein concentration by $26 \%$ in grass. Norton et al. (1990) said that forage grown under canopy had higher nitrogent content than forage grown on the open field. High nitrogent content was caused by canopy ease nitrogent availability in soil to be absorbed by plant and then increasing nitrogent content in plant tissue (Wilson \& Ludlow 1991; Wong \& Wilson 1980). Yayneshet et al. (2009) reported that crudeprotein content from forage in semi-arid area in Ethiopia drastically decreased which was caused by dry and soil acidity stresses. Higher structural component (NDF, ADF and ADL) content found during dry season especially in acid soil was alegedly due to high lignification and maturiry stadium of plant (Hussain \& Durrani 2009). Khan et al. (2008) said that overuse of organic fertilizer would damage soil structure, increase soil acidity, cause nutritional imbalance, and decrase production and quality of plant.

Based on analysis of variance, there was no interaction between oil palm canopy and soil acidity to crude fiber content of $I$. zollingeriana (Table 6). Crude fiber content under 2 years oil palm trees was significantly $(\mathrm{P}<0.05)$ lower by $13.57 \%$ than under 5 and 7 years oil palm treatment by 17.66 and $17.90 \%$, respectively. Crude fiber under 5 and 7 years oil palm trees did not different significantly. Then crude fiber content in neutral and acid soil did not show a difference. Blair et al. (1983) reported than crude protein content and cell wall consistency such as ADF and cellulose increased along with canopy density increase. Humphreys (2005) also said that canopy would change quality of light spectrume which would be up on the leaf surface affecting in tiller and germanisation. Light, one of components of photosynthesis process conversed carbone monoxide and water into glucose and structure carbone forming cell wall, cellulose and hemicellulose. Decrease of light intencity did not affect lygnin level, however the highest lygnin content was schieved in dense canopy shade (Blair et al. 1983).

There was no interaction between oil palm canopy and soil acidity to energy content of I. zollingeriana (Table 7). Energy content under 7 years oil palm treatment was significantly $(\mathrm{P}<0.05)$ higher by 4015.0 $\mathrm{Kcal} / \mathrm{kg}$ than under the 2 and 5 years oil palm treatment by 3749.0 and $3895.3 \mathrm{Kcal} / \mathrm{kg}$, respectively. Energy content in neutral was significantly lower by 3790.3 $\mathrm{Kcal} / \mathrm{kg}$ than in acid soil by $3982.5 \mathrm{Kcal} / \mathrm{kg}$. Increase of canopy level increases forming of structure carbone in plant cell wall increasing crude fiber content. Energy was a metabolism product of energy resource foods such as carbohydrate including crude fiber, cellulose, hemicellulose and lygnin digested by ruminal microbes in the digestive tract (Dewhurst et al. 2009). Energy producted from that metabolic process was used for maintenance; growth and production of milk, meat, egg, and wool (William 2010). Gross energy was one of crude fiber methabolic products in ruminant digestive tract with ruminal enzyme and microbes help. As reported by Dewhurst et al. (2009) that increase of gross energy of forage was alwasy in line with increase of crude fiber of dry material of forage especially cellulose 
Table 7. Energy content of I. zollingeriana in various canopy levels and soil acidity (\%) of oil palm estate

\begin{tabular}{lllll}
\hline \hline \multirow{2}{*}{ Soil acidity } & \multicolumn{3}{c}{ Canopy level (age of oil palm) } & Average \\
\cline { 2 - 4 } & 2 years & 5 years & 7 years & $3790.3^{\mathrm{b}}$ \\
\hline Neutral & 3406.0 & 3875.0 & 4090.0 & $3982.5^{\mathrm{a}}$ \\
\hline Acid & 4384.5 & 3623.0 & 3940.0 & $4015.0^{\mathrm{a}}$ \\
\hline Average & $3895.3^{\mathrm{b}}$ & $3749.0^{\mathrm{c}}$ & & \\
\hline
\end{tabular}

The different letters in column and row shows significant difference $(\mathrm{P}<0.05)$

Table 8. Calcium (Ca) content of I. zollingeriana in various canopy levels and soil acidity (\%) of oil palm estate

\begin{tabular}{lcccc}
\hline \hline \multirow{2}{*}{ Soil acidity } & \multicolumn{3}{c}{ Canopy level (age of oil palm) } & \multirow{2}{*}{ Average } \\
\cline { 2 - 4 } & 2 years & 5 years & 7 years & $1.19^{\mathrm{a}}$ \\
\hline Neutral & 0.92 & 0.94 & 1.71 & $0.83^{\mathrm{b}}$ \\
Acid & 0.78 & 0.81 & 0.90 & $1.31^{\mathrm{a}}$ \\
\hline Average & $0.85^{\mathrm{b}}$ & $0.88^{\mathrm{b}}$ & \\
\hline
\end{tabular}

The different letters in column and row shows significant difference $(\mathrm{P}<0.05)$

component which ease to be hydrolized by acid or cellulose enzyme resulted by ruminal microorganism into monomer glucose. Karim et al. (1991) reported that increase of plant age and dry stress decreased ratio of leaves/stems, meanwhile increased ratio of stems/leaves. This decreased crude protein content, but instead increased gross energy. The most gross energy in plant is in stem due to carbohydrate content in the form of crude fiber (cellulose, hemicellulose and lignin).

There was no interaction between oil palm canopy and soil acidity to calcium (Ca) content of $I$. zollingeriana (Table 8). Calcium (Ca) content under 7 years oil palm trees was significantly $(\mathrm{P}<0.05)$ higher by $1.31 \%$ than under the 2 and 5 years oil palm trees by 0.85 and $0.88 \%$, respectively, however there was no significant difference between 2 and 5 years oil palm canopy treatment. Then, Ca content in neutral soil was significantly higher $(\mathrm{P}<0.05)$ by $1.19 \%$ than in acid soil by $0.83 \%$. Blair et al. (1983) said that concentration of phosphor and calcium was significantly higher under dense canopy than under medium canopy and without canopy.

There was no interaction between oil palm canopy and super dolomit administration to phosphor of $I$. zollingeriana (Table 9). There was no significant difference between canopy level under 2, 5, and 7 years oil palm to phosphor content, as well as in soil acidity level. Blair et al. (1983) reported that phosphor (P) and calcium $(\mathrm{Ca})$ concentration was significantly higher under dense canopy than under medium canopy and without canopy. Congdon \& Addison (2003) said that N concentration in leaves was greatly influenced by canopy, where its concentration increased under canopy than control, whereas it did not change significantly to concentration of phosphor in leaves.

Based on analysis of variance, there was no interaction between oil palm canopy and soil acidity to dry material digestibility of I. zollingeriana (Table 10). Digestibility of dry material under 2 years oil palm trees was significantly $(\mathrm{P}<0.05)$ higher by $71.53 \%$ than under 5 and 7 years oil palm trees by 65.45 and $62.78 \%$, respectively. It was significantly higher by $67.20 \%$ in neutral soil than in acid soil by $65.98 \%$.

Digestibility of dry material decreased, because closer canopy would increase crude fiber in plant. Blair et al. (1983) reported that dry material digestibility was very good under full sunlight or medium canopy. Dry material digestibility by in vitro was the number of digestable and not excreted dry material in the form of faecess and was assumed as a part absorbed by animal (Chuzaemi \& Bruchem 1990). One of the reasons of low dry material digestibility was high lygnin content in skin cell wall of plant which might prevent enzyme to normaly digest fiber. Sleugh et al. (2001) reported that decrease of dry material digestibility was in line with frequency of prunning due to accumulation of indigestible fiber, lignification increase and decrease of leaves/branches ratio, would form cell wall structure making it difficult to be digested by ruminal microbes. Digestibility value of grass and legume, generally decreased along with plants aged and decrease of soil water content due to increase of crude fiber concentration in plant tissue, increase of lignification and decrease of ratio leaves/stems (Nisa et al. 2004). 
Herdiawan. Productivity of Indigofera zollingeriana under different canopy and soil acidity level in oil palm estate

Table 9. Phospor content I. zollingeriana in various canopy levels and soil acidity (\%) of oil palm estate

\begin{tabular}{lcccc}
\hline \hline \multirow{2}{*}{ Soil acidity } & \multicolumn{3}{c}{ Canopy level (age of oil palm) } & Average \\
\cline { 2 - 4 } & 2 years & 5 years & 7 years & $0.27^{\mathrm{a}}$ \\
\hline Neutral & 0.28 & 0.27 & 0.27 & $0.26^{\mathrm{a}}$ \\
Acid & 0.26 & 0.26 & 0.26 & $0.27^{\mathrm{a}}$ \\
\hline Average & $0.27^{\mathrm{a}}$ & $0.27^{\mathrm{a}}$ & & \\
\hline
\end{tabular}

The different letters in column and row shows significant difference $(\mathrm{P}<0.05)$

Table 10. Digestibility of dry material of I. zollingeriana in various canopy level and soil acidity (\%) of oil palm estate

\begin{tabular}{lcccc}
\hline \multirow{2}{*}{ Soil acidity } & \multicolumn{3}{c}{ Canopy level (age of oil palm) } & Average \\
\cline { 2 - 4 } & 2 years & 5 years & 7 years & $67.20^{\mathrm{a}}$ \\
\hline Neutral & 70.65 & 67.65 & 63.29 & $65.98^{\mathrm{b}}$ \\
\hline Acid & 72.41 & 63.25 & 62.27 & $62.78^{\mathrm{c}}$ \\
\hline Average & $71.53^{\mathrm{a}}$ & $65.45^{\mathrm{a}}$ & \\
\hline
\end{tabular}

The different letters in column and row shows significant difference $(\mathrm{P}<0.05)$

Table 11. Digestibility of organic material of I. zollingeriana in various canopy levels and soil acidity (\%) of oil palm estate

\begin{tabular}{lcccc}
\hline \hline \multirow{2}{*}{ Soil acidity } & \multicolumn{3}{c}{ Canopy level (age of oil palm) } & \multirow{2}{*}{ Average } \\
\cline { 2 - 4 } & 2 years & 5 years & 7 years & $64.71^{\mathrm{a}}$ \\
\hline Neutral & 70.16 & 63.65 & 60.32 & $63.58^{\mathrm{b}}$ \\
\hline Acid & 68.62 & 61.25 & 60.86 & $60.59^{\mathrm{c}}$ \\
\hline Average & $69.39^{\mathrm{a}}$ & $62.45^{\mathrm{b}}$ & & \\
\hline
\end{tabular}

The different letters in column and row shows significant difference $(\mathrm{P}<0.05)$

Based on analysis of variance, there was no interaction between oil palm canopy and soil acidity to organic material digestibility of $I$. zollingeriana (Table 11). Organic material digestibility under 2 years oil palm trees was significantly higher by $69.39 \%$ than those under 5 and 7 years oil palm trees by 62.45 and $60.59 \%$, respectively. Then organic material digestibility in super dolomit administration treatment was significantly $(\mathrm{P}<0.05)$ higher by $64.71 \%$ than in soil without super dolomit by $63.58 \%$.

Digestibility of organic material of forage was organic material value including crude protein, carbohydrate, fiber to digest and not excreted through faecess and might be used as indicator of overall forage quality. Low digestibility of organic material as well as dry material digestibility was caused by high crude fiber, expecially lygnin in its basic material of forage. The highest and lowest digestibility of organic material of I. zollingeriana by $76.02 \%$ and $63.86 \%$, respectively was still higher than digestibility of Gliricidia sepium by $60.82 \%$ (Sánchez et al. 2005). González \&
Hanselka (2002) said that digestibility of organic material of forage decreased significantly from rainy to dry season in line with increase of some crude fiberforming components. (Hassen et al. 2007) stated that all of Indigofera species had higher ash, crude protein, and organic material digestibility with lower NDF concentration in spring.

\section{CONCLUSION}

Denser canopy level of oil palm (5 and 7 years old) significantly decreased fresh production of $I$. zollingeriana either in netral and acid soil. Nutrient content of CP, CS, energy, $\mathrm{Ca}$ and $\mathrm{P}$ of I. zollingeriana increased along with level increase of oil palm canopy shade (5 and 7 years old), otherwise digestibily of dry and organic material were decrease. I. zollingeriana was not tolerant to dense oil palm canopy ( 5 and 7 years old), but had better quality and quantity in lesser canopy dense ( 2 years old). 


\section{REFERENCES}

Abdullah L. 2011. Prospek integrasi perkebunan kelapa sawitsapi potong dalam upaya percepatan pencapaian swasembada daging nasional 2014: Sebuah tinjauan perspektif penyediaan pakan. Sangatta (Indones): Sekolah Tinggi Ilmu Pertanian Kutai Timur.

Atman. 2006. Pengelolaan tanaman kedelai di lahan kering masam. J Ilm Tambua. 5:281-287. doi: 10.1080/14620316.2012.11512822.

Atwell B, Kriedemann P, Turnbull C. 1999. Plants in action adaptation in nature, performance in cultivation. South Yarra (Aust): McMillan Education Australia Pty., Ltd.

Batubara A, Kasup I, Kesma AA, Irfan A, Simanjuntak H, Harahap P. 1999. Kajian integrasi penggemukkan ternak sapi potong di lahan perkebunan kelapa sawit. Bogor (Indonesia): Balai Penelitian Ternak.

Bertin N, Gary C. 1998. Short and long term fluctuations of the leaf mass per area of tomato plants - Implications for growth models. Ann Bot. 82:71-81. doi: 10.1006/anbo.1998.0647.

Blair RM, Rene A, Austin H. 1983. Shade intensity influences the nutrient quality and digestibility of southern deer browse leaves. J Range Manag. 36:257-263. doi: $10.2307 / 3898177$.

[CSA] Central Statistic of Agency. 2012. Statistik Indonesia 2012. Jakarta (Indones): Central Statistic of Agency.

Chen LS, Qi YP, Smith BR, Liu XH. 2005. Aluminuminduced decrease in $\mathrm{CO}_{2}$ assimilation in citrus seedlings is unaccompanied by decreased activities of key enzymes involved in $\mathrm{CO}_{2}$ assimilation. Tree Physiol. 25:317-324.

Chin FY. 1998. Sustainable use of ground vegetation under mature oil palm and rubber trees for commercial beef production. de la Vina AC, Moog FA, editors. Proceeding of 6th Meeting Region Work Grazing Feed Resources Southeast Asia. Rome (Italy): Food Agriculture of Organization. p. 35-44.

Chuzaemi S, Bruchem JV. 1990. Fisiologi nutrisi ruminansia. KPK UGM-Brawijaya. Program Pascasarjana. Spesialisasi pakan ternak. Malang (Indones): Universitas Brawijaya.

Congdon B, Addison H. 2003. Optimising nutrition for productive and sustainable farm forestry systems pasture legumes under shade. A report for the RIRDC/Land \& Water Australia/FWPRDCMDBC. Joint Venture Agroforestry Program. Townsville (Aust): James Cook University.

Crowder LV, Chheda HR. 1982. Tropical grassland husbandry. New York (USA): Longman Group.

Daru TP, Yulianti A, Widodo E. 2014. Potensi hijauan di perkebunan kelapa sawit sebagai pakan sapi potong di kabupaten Kutai Kartanegara. Media Sains. 7:79-86.

Das DK, Chaturvedi OP, Mandal MP, Kumar R. 2008. Effect of tree plantations on biomass and primary productivity of herbaceous vegetation in eastern India. Trop Ecol. 49:95-101.

Dewhurst RJ, Delaby L, Moloney A, Boland T, Lewis E. 2009. Nutritive value of forage legumes used for grazing and silage. Ir J Agric Food Res. 48:167-187.

D1'az-Pe'rez JC. 2013. Bell pepper (Capsicum annum L.) Crop as affected by shade level: microenvironment, plant growth, leaf gas exchange, and leaf mineral nutrient concentration. HortScience. 48:175-182.

Farizaldi. 2011. Produktivitas hijauan makanan ternak pada lahan perkebunan kelapa sawit berbagai kelompok umur di PTPN 6 Kabupaten Batanghari Propinsi Jambi. J Ilmu Peternak. 11:75-78.

González VEA, Hanselka CW. 2002. Ecología y manejo de matorrales. Caso provincia biótica tamaulipeca. Mexico (USA): INIFAP-Texas A\&M University, Social and Comercial Press.

Hairiah K, Rahayu S, Berlian. 2006. Layanan lingkungan agroforestri berbasis kopi: Cadangan karbon dalam biomasa pohon dan bahan organik tanah (studi kasus dari Sumberjaya, Lampung Barat). Agrivita. 28:298309.

Hanafi ND, Umar S, Bachari I. 2005. Pengaruh tingkat naungan pada berbagai pastura campuran terhadap produksi hijauan. J Agribisnis Peternak. 1:100-105.

Hassen A, Rethman NFG, van Niekerk WA, Tjelele TJ. 2007. Influence of season/year and species on chemical composition and in vitro digestibility of five Indigofera accessions. J Anim Feed Sci Technol. 136:312-322. doi: 10.1016/j.anifeedsci.2006.09.010.

Herdiawan I, Sutedi E. 2013. Productivity of Calliandra calothyrsus, Indigofera zollingeriana and Gliricidia sepium on acid soil in the greenhouse. Indones J Anim Vet Sci. 20:105-114. doi: 10.14334/jitv.v20i2.1165.

Hilman Y, Kasno A, Saleh N. 2004. Kacang-kacangan dan umbi-umbian: Kontribusi terhadap ketahanan pangan dan perkembangan teknologinya. In: Makarim, editor. Inovasi pertanian tanaman pangan. Bogor (Indones): Indonesian Center for Food Crops Research and Development. p. 95-132.

Horne PM. 1994. Agroforestry plantation system : Sustainable forage and animal in rubberand oil palm plantation. In: Copland JW, Djajanegara A, Sabrani M, editors Agroforestry and Animal Production for Human Welfare at 7th Animal Science Congress of AsiaAustralasian Animal Production. Bali (Indonesia): ACIAR.

Humphreys LR. 2005. Tropical pasture utilitisation. Cambridge (UK): Cambridge University Press.

Hussain F, Durrani MJ. 2009. Nutritional evaluation of some forage plants from Harboi rangeland, Kalat, Pakistan. Pak J Bot. 41:1137-1154.

Jaramillo BC, Santos RHS, Martinez HEP, Fardin MP. 2010. Production and vegetative growth of coffee trees under 
fertilization and shade levels. Sci Agric. 67:639-645. doi: 10.1590/S0103-90162010000600004.

Karim AB, Rhodes ER, Savill PS. 1991. Effect of cutting interval on dry matter yield of Leucaena leucocephala (Lam) De Wit. Agrofor Syst. 16:129-137. doi: 10.1007/BF00129744.

Kephart KD, Buxton DR. 1993. Forage quality responses of $\mathrm{C}_{3}$ and $\mathrm{C}_{4}$ perennial grasses to shade. Crop Sci. 33:831837.

Khan HZ, Malik MA, Saleem MF. 2008. Effect of rate and source of organic material on the production potential of spring maize (Zea mays L.). Pak J Agric Sci. 45:40-43.

Kittas C, Katsoulas N, Rigakis N, Bartzanas T, Kitta E. 2012. Effects on microclimate, crop production and quality of a tomato crop grown under shade nets. J Hortic Sci Biotechnol. 87:7-12.

Larcher W. 1995. Physiological plant ecology. Ecophysiological and stress physiology of functional groups. In: Demming-Adams B, Adams III WW, Borchert R, van Bel AJE, Ernst WHO, Kappen L, Korner C, Kuppers M, Ma JF, Richter H, et al., editors. 4th ed. Berlin (Germany): Springer.

Mulyani A, Ritung S, Las I. 2011. Potensi dan ketersediaan sumber daya lahan untuk mendukung ketahanan pangan. J Litbang Pertan. 30:73-80.

Nisa M, Sarwar M, Khan MA. 2004. Nutritive value of urea treated wheat straw ensiled with or without coern steep liquor for lactating Nili-ravi buffaloes. Asia-Austral J Anim Sci. 17:825-829. doi: 10.5713/ajas.2004.825.

Norton BW, JR Wilson JR, Shelton HM, Hill KD. 1990. Urea treated wheat straw with or without corn steep liquor on feed consumption, digestibility and milk yield and its composition in lactating Nili-ravi buffaloes. Forages for plantation crops. In: Proceeding Work. Bali (Indones); p. 83-88.

Qifu MA, Rengel Z, Kuo J. 2002. Aluminium toxicity in rye (Secale cereale): root growth and dynamics of cytoplasmic $\mathrm{Ca}^{2+}$ in intact root tips. Ann Bot. 89:241244.

Sánchez MI, Green AJ, Castellanos EM. 2005. Seasonal variation in the diet of the redshank Tringa totanus in the Odiel Marshes, south-west Spain: A comparison of faecal and pellet analysis. Bird Study. 52:210-216. doi: $10.1080 / 00063650509461393$

Shehu Y, Al-Hassan WS, Pal UR, Philips CSJ. 2001. Yield and chemical composition response of Lablab purpureus to nitrogen, phosphorus and potassium fertilizers. Trop Grassl. 35:180-185.

Sleugh BB, Moore KJ, Brummer EC, Knapp AD, Russell J, Gibson L. 2001. Forage nutritive value of various Amaranth species at different harvest dates. Crop Sci. 41:466-472.

Subagyo H, Suhartab N, Siswanto AB. 2004. Tanah-tanah pertanian di Indonesia. Dalam: Sumberdaya lahan Indonesia dan pengelolaannya. Adimihardja A, Amien LI, Agus F, Djaenudin D, editors. Bogor (Indones): Indonesian Center for Agricultural Land Resources Research and Development.

William PW. 2010. Refining the net energy system. WCDS Adv Dairy Technol. 22:191-202.

Wilson JR, Ludlow MM. 1991. The environment and potential growth of herbage under plantations. Stur WW, editor. ACIAR Proceeding of Forages Plant Crop. Canberra (Aust): Australian Centre for International Agricultural Research. p. 10-24.

Wilson JR, Wild DWM. 1995. Nitrogen availability and grass yield under shade environments. In: Mullen BF, Shelton HM, editors. ACIAR 64 - Integration Ruminants into Plant System in Southeast Asia. Canberra (Aust): Australian Centre for International Agricultural Research.

Wong CC, Chin FY. 1998. Meeting nutritional and requirement of cattle from natural forages in oil plantation. In: Proceeding of National Seminar Livestock Crop Integration Oil Palm-Toward Sustainable. Johor (Malays): Palm Oil Research Institute of Malaysia. p. 10-19.

Wong CC, Wilson JR. 1980. Effect of shading on growth and nitrogen content of green panic and siratro in pure and mixed swards defoliated at two frequencies. Aust J Agric Res. 31:269-185.

Yayneshet T, Eik LO, Moe SR. 2009. Seasonal variations in the chemical composition and dry matter degradability of enclosure forages in the semi-arid region of Northern Ethiopia. J Anim Feed Sci Technol. 148:12-33. 